\title{
The Adoption of Sustainable Facilities Management (SFM) by the Hotel Industry
}

\author{
Alyaa Afifah Abu Talib1, Nor Rima Muhamad Ariff', Mohamad Sufian Hasim¹, Mohd Hafiz Hanafiah² \\ ${ }^{1}$ Centre of Studies for Postgraduate, Faculty of Architecture Planning and Surveying, ${ }^{2}$ Faculty of Hotel and Tourism Management, \\ Universiti Teknologi MARA, Shah Alam, Selangor \\ alyaaafifa@gmail.com,norri550@uitm.edu.my,moham315@uitm.edu.my, hafizhanafiah@uitm.edu.my \\ Tel. +60162218659
}

\begin{abstract}
Sustainability issues within the hotel industry are now increasingly known as a significant concern around the world. It has been described as a constituent activity that contributes to a significant impact on the environment. However, the concept of sustainable management is yet to be well received by the hotel industry in Malaysia. This paper aims to study the growing idea of Sustainable Facilities Management (SFM) adoption, specifically in the hotel industry. This paper provides valuable information on the theory of SFM evolution, including the meta-analysis on the SFM developing, trends and researchers around the world. This paper identified a total of 15 hospitality initiatives utilized around the globe, with only nine of them are currently employed and adopted by the hotel industry. These initiatives are essential that need to be implemented in a hotel organization to gain successful and holistic SFM practices adoption.
\end{abstract}

Keywords: Sustainable; Sustainability Facilities Management (SFM); Hotel.

eISSN: 2398-4287 @ 2019. The Authors. Published for AMER ABRA cE-Bs by e-International Publishing House, Ltd., UK. This is an open access article under the CC BYNC-ND license (http://creativecommons.org/licenses/by-nc-nd/4.0). Peer-review under responsibility of AMER (Association of Malaysian Environment-Behaviour Researchers), ABRA (Association of Behavioural Researchers on Asians) and cE-Bs (Centre for Environment-Behaviour Studies), Faculty of Architecture, Planning \& Surveying, Universiti Teknologi MARA, Malaysia.

DOI: https://doi.org/10.21834/e-bpj.v4i12.1927

\subsection{Introduction}

Malaysia has reaffirmed with the United Nations Sustainable Development Summit to support and commitment to implement the 2030 Agenda for Sustainable Development and its 17 Sustainable Development Goals (17SDGs). In aligning with Malaysia National Ecotourism Plan (MNEP) (2016): Chapter 1- Strategic 3, Action 4 agenda, the hotel industry is urged to adhere to the sustainability principles and practices in the existing hotels. The persistence is to support the 17 SDGs global goal since the sustainability issues in the hotel industry are now increasingly known as a significant concern (United Nations World Tourism Organization (UNWTO), 2018). A wide recognition across the globe by many organization on the sustainability practices were showed from plenty of evidence (Hasim et al., 2012). Although the studies on sustainability concern had been well researched in various settings (Alonso-Almeida, et al., 2017; Bohdanowicz, 2005; Nielsen, Sarasoja, \& Galamba, 2016), there is still lack of evidence from the hotel industry.

In terms of sustainability, the hotel industry's sustainability concept had begun to gain momentum in this industry recently (Ernst and Young, 2013). Globally, accommodation (e.g. hotel, motel, holiday apartments, camping ground) is responsible for an estimated $21 \%$ of pollutions and emissions from tourism (United Nation Environmental Protection (UNEP), 2017; United Nations Environment Program (UNEP), 2008). Thus, many hotel organizations have considered implementing sustainable initiatives practice such as, reducing waste, energy and water consumption, in which they agreed these practices resulted in a positive impact to the environment while it offers

eISSN: 2398-4287 @ 2019. The Authors. Published for AMER ABRA cE-Bs by e-International Publishing House, Ltd., UK. This is an open access article under the CC BYNC-ND license (http://creativecommons.org/licenses/by-nc-nd/4.0). Peer-review under responsibility of AMER (Association of Malaysian Environment-Behaviour Researchers), ABRA (Association of Behavioural Researchers on Asians) and cE-Bs (Centre for Environment-Behaviour Studies), Faculty of Architecture, Planning \& Surveying, Universiti Teknologi MARA, Malaysia. DOI: https://doi.org/10.21834/e-bpj.v4i12.1927 
economic benefits in return (UNEP, 2008). Besides, UNEP (2008) reported that hotel environmental management programs could also have significant repercussions for positive stakeholder's perceptions.

Previous studies had reported that sustainability facilities management had become a necessary practice to adopt in hotel industry these days to maintain their competitive position (Alonso-Almeida et al., 2017; Bruns-smith et al., 2015; International Facility Management Association (IFMA), 2018; Jenkins et al., 2014; Junghans et al., 2014; Nielsen et al., 2016). Besides, International Facility Management Association(IFMA) reported, natural resources have depleted, which pushing Facility Management (FM) professionals to develop competencies in areas of sustainable development and practices within their organizations (IFMA, 2018). Based on the literature, there seems to be a full recognition of the benefits and importance of incorporating sustainability into FM practice (AlonsoAlmeida et al., 2017; Baaki et al., 2016; Elmualim et al., 2012; Elmualim et al., 2009; Jenkins \& Karanikola, 2014; Nielsen et al., 2016) however, studies and literature focusing on the drivers of SFM are very few particularly in hotel industry. Hence, the study is to focus on the Sustainable Facilities Management (SFM) practices within hotel industry. The focus of this paper is to identify the key initiatives of SFM implemented for the hotel industry in Malaysia.

\subsection{Literature Review}

\subsection{Facilities Management (FM)}

Facilities Management (FM) has evolved from property to the construction industry as well as recognized in other sector industries. Presently, FM has acknowledged as the fastest emerging and most important sector in many industries, having gained recognition from the 1970s when outsourcing services became popular in radical cost-cutting initiatives (Alexander, 2009). Since then, in the late 80s and early 90s, it has been witnessed as rapid development growth (Meng, 2015). FM is well known for its emerging, multi-disciplinary professions that cover a variety of services from core to non-core function of delivering the strategic decision-making process. Besides typically seen in the operational sense of cleaning, care-taking, repairs and maintenance, FM now covers "real estate management, financial management, change management, human resources management, health and safety, contract management, in additional to building and engineering services maintenance, domestic services and utilities supplies" (Alexander, 2009; International Facility Management Association (IFMA), 2018). A chronology of how FM has transformed is provided by (Alexander, 2009 ) as per Table 1.

\begin{tabular}{cclc} 
& & \multicolumn{1}{c}{ Table 1: Evolution of FM (sources: Alexander, 2009) } \\
\hline Period & Generation & \multicolumn{1}{c}{ Activity } & Level \\
\hline $1970 s$ & $1^{\text {st }}$ & Managed services, outsourcing, total facilities management, CAFM & Operational \\
\hline $1980 s$ & $2^{\text {nd }}$ & Quality management, management agency, benchmarking, FM process, FMIS & Strategic \\
\hline $1990 s$ & $3^{\text {rd }}$ & $\begin{array}{l}\text { Partnering, re-engineering processes, knowledge management, product innovation, } \\
\text { Sustainable Facilities Management (SFM) }\end{array}$ \\
\hline $2000 \mathrm{~s}$ & $4^{\text {th }}$ & $\begin{array}{l}\text { Business processes, open innovation, usability, service excellence transformational } \\
\text { outsourcing }\end{array}$ \\
\hline
\end{tabular}

Today, sustainability adaptation into FM practice is not an odd context, yet it supports to deliver more effective and competent strategic in business organizations. As highlighted by Nielsen et al. (2016), the implementation of sustainability in FM practice is significant in the strategic response of any business entity. Nonetheless, the process of integrating sustainability into FM practices is not the same for all organizations. The integration is unique for the specific type of business as they differ in terms of facility features, organizational scale, business sector, organization characteristics, the context of operation and culture (Chotipanich, 2006). For instance, the FM needs to comply in diverse types such as; residential, educational, institutional, industrial, hospitality and vary in terms of the building engineering system, ownership, scale, location and building type (Nazeer, Gunatilake, \& Ramachandra, 2019). According to Hodges (2014), the notion of sustainability discipline of FM competency in the strategic level was recognized since the 1990s (Table 1). Notably, the integration of sustainability stewardship competency in FM areas propensities into environment-behaviour and it is significantly the top core competencies for facility managers in managing either built and natural environments. Hodges (2014) added, sustainability in FM is holistically deliberate and strategically mature in sustaining for the environment-behaviour, which generate highperformance standard (Table 2).

Table 2: Holistic proficiency of SFM

\begin{tabular}{cl}
\hline Organization Level & \multicolumn{1}{c}{ Roles of SFM in Organization } \\
\hline Strategic Level & $\begin{array}{l}\text { Establish vision and demonstrate policy in responsibility for long term direction, goal setting and decision } \\
\text { making }\end{array}$ \\
\hline Tactical Level & Communicate the policy of SFM strategy and continuous improvements initiatives \\
\hline Operational Level & Execute day-to-day management and participate in performance development \\
\hline \multicolumn{1}{c}{ (sources: Hodges, 2014) }
\end{tabular}

Additionally, the nature of sustainability practices varies; whether reducing energy usage, improving energy efficiency, increasing the use of renewable energy, carbon offsetting strategies, sustainable destination planning and management, as well as other changes in business practices (United Nations Environment Program (UNEP), 2008). Hence, sustainable practice is a significantly important area 
in FM professionals, in which they need to develop their competencies to face the future demands, challenges and opportunities of sustainable development and practices (British Institute of Facilities Management (BIFM), 2018).

\subsection{Sustainable Facilities Management (SFM)}

According to International Facility Management Association (IFMA) (2018), defined Sustainable Facilities Management (SFM) as a process of integrating the people, place, and business of an organization in a way that optimizes economic, environmental and social benefits of sustainability. In other words, SFM extrapolated as the delivery of sustainability stewardship within the FM context. The IFMA emphasized the need for facilities managers to retain the ability to make a "business case for sustainability" and develop sustainability initiatives practices. Similarly, identified integrating all sustainability considerations, linking strategic level with operational level, incorporating FM knowledge and experience into the design, disseminating sustainable knowledge and educating people, encouraging sustainability through innovation as crucial roles facilities managers could play in sustainable FM practice (IFMA, 2018).

Sustainable development is now accepted as a critical success factor and a notion applicable to both governments and in any industry (Brundtland International Institute for Sustainable Development, 2017). Since then, the notion of sustainability development had been mentioned in various international platforms and, the movement towards "sustainability" had been expanded across the globe. The general idea of sustainable facilities management (SFM) is to incorporate sustainability practices into the operations and implementation of facilities management functions. In essence, SFM is not a new practice but instead merging practices of integrated principles concerning social, economic and environmental policies of sustainability into the existing notion of FM. As a logical conclusion, this highlights the need for more multi-disciplinary and trans-disciplinary research to support the emerging discipline of SFM in the hotel industry.

Today, SFM is well-acknowledged as a best practice employed by companies worldwide. The focus on sustainability helps organizations manage their social and environmental impacts and improve their operating efficiency and natural resource stewardship. The movement towards a greater emphasis on sustainability, world infrastructure, and technology received various incentives, momentum and occasionally obligation to adapt accordingly to its associated trends. Since then, Sustainable Facilities Management (SFM) has been identified as one of the emerging themes in the future of FM research has been one of the top research themes in EuroFM network (Junghans \& O.E. Olsson, 2014) and an increasing number of published research articles and discussions (Nielsen et al., 2016a).

\subsection{SFM and the hotel industry}

Sustainability concern encompasses most industries (Iwanowski \& Rushmore, 1994) and people are becoming increasingly aware of the damage inflicted on the environment by business activities, changing consumers' behaviours and company operations(Jenkins \& Karanikola, 2014). The past several decades have seen a growing awareness amongst hoteliers regarding the environmental and social impacts of hotel development and operations on the extent where sustainability issues have permeated nearly every aspect in the hotel industry. The growing sustainability awareness had driven multiple factors, including owners' and operators' desires to reduce operational costs, changing investor attitudes toward the environment, the increased regulatory focus on facility operations and development, and a customer shift towards greener hotels (Goldstein \& Primlani, 2012). The roots of sustainability thought in the hotel industry became evident over half a century ago, when a few hoteliers realized they could provide an enhanced guest experience by integrating natural/green elements into the customers' staying experience (Goldstein \& Primlani, 2012).

Consequently, managing the facilities well helps to improve a hotel's efficiency and adds value to their performance and services (Penny, 2007). However, without proper integration of sustainability's hotel FM, the core businesses of hotels (e.g. guestrooms, food, and beverages) would be affected negatively (Durodola et al., 2012). It is important to note that the hotel industry generates a lot of adverse environmental impacts which are often associated with excessive consumption (UNEP, 2008) of local and imported non-durable goods, energy and water, followed by emissions released to air, water, and soil (Penny, 2007). Many researchers have report that improving hotel environmental performances would lead to the reduction of energy consumption and operational costs (Bruns-smith et al., 2015; Göğüş et al., 2013; Melissen et al., 2016), generate an environmentally-friendly environment for both staff and customers and help raising the company's corporate image and gaining the competitive edge (Baaki et al., 2016; Jayawardena et al., 2013; Jenkins \& Karanikola, 2014; Nielsen et al., 2016; Zaiton et al., 2016). Accordingly, Baaki et al., (2016) and; Lai \& Choi, (2015) have highlighted the importance of adopting a holistic approach of sustainability, in which by assessing the SFM practice. Also, Baaki et al., (2016), stated that it is a necessity for determining the SFM initiatives to be implemented in the organizations. The SFM approach in the hotel organizations is vital that contemporary managers recognize the specificities enshrouded in economics, society, and environment by observing systemic issues within their organizational structure. Thus, it is crucial to create criteria capable of inducing modern management to employ SFM practices that entwined to ethical and responsible values specificities from any organization. The Association of Southeast Asian Nations (ASEAN) was established in 2016 as a guideline of 'ASEAN Green Hotel Standard' for hotel organizations to increase the Environmentally-friendly and Energy Conservation in the ASEAN Accommodation industry, with a unified agreement across the ASEAN Members States (ASEAN, 2016). However, in Malaysia, the SFM practice within the hotel industry is still lacking and limited (Yusof \& Jamaludin, 2013; Zaiton et al., 2016). In particular, most of the hotel FM efforts should be channelled to improve organizational effectiveness and well-being by adopting the SFM approach in addressing the issues of environmental management in the hotel industry (Lai \& Choi, 2015). 


\subsection{Methodology}

This study gathered and reviewed the SFM practice around the globe and was then merged with information before the literature on the particular initiatives that apply to the hotel industry. A qualitative approach was used in this study to gather the research data. The metaanalysis systematically analyzed available guidelines of sustainable practice for the hotel industry around the world (Table 2). The purpose of the meta-analysis is to review a variety of existing sources (e.g., documents, reports, data files, and other written artefacts) to collect independently verifiable data and information (Bowen, 2009; Neuman, 2014). Bowen (2009) also defined that meta-analysis is a systematic procedure for reviewing or evaluating documents, either both printed and electronic (computer-based and Internettransmitted) material. Like other analytical methods in qualitative research, meta-analysis requires that data be examined and interpreted to elicit meaning, gain understanding, and develop empirical knowledge (Creswell, 2014; Neuman, 2014).

\subsection{Findings \& Discussion}

Table 3 below shows a total of 15 initiatives were discover from the documents analyzed. There are ten countries and continents who published their strategic plans of SFM practice and guidelines for the hospitality sector. They are the United States of America (EPA, LEED, Green Globe, Green Seal), United Kingdom (Green Tourism, Global Sustainable Tourism Council-GSTC), European countries (EMS/ EMAS), New Zealand (Green Globe), Australia (earth-check), Canada (Green Key Global), China (LEED, CST), Japan (GSTC) and ASEAN countries (ASEAN Tourism Strategic Plan -ATSP , ASEAN Green Hotel Standard-AGHS). The strategic sustainable initiatives for the hotel industry are presented in Table 4.

Table 3: Strategic sustainable initiatives for the hotel industry across the globe

\begin{tabular}{|c|c|c|c|c|c|c|c|c|c|c|}
\hline $\begin{array}{l}\text { Countryl } \\
\text { Continents } \\
\text { Sustainable } \\
\text { initiatives }\end{array}$ & $\begin{array}{c}\text { US } \\
\text { (EPA,Green } \\
\text { Globe,LEED, } \\
\text { Green Seal) }\end{array}$ & $\begin{array}{c}\text { UK } \\
\text { (Green } \\
\text { Tourism, } \\
\text { GSTC) }\end{array}$ & $\begin{array}{c}\text { EU } \\
\text { (EMAS/E } \\
\text { MS) }\end{array}$ & $\begin{array}{c}\text { New } \\
\text { Zealand } \\
\text { (Green } \\
\text { Globe) }\end{array}$ & $\begin{array}{c}\text { Australia } \\
\text { (earth- } \\
\text { check) }\end{array}$ & $\begin{array}{c}\text { Canada } \\
\text { (Green } \\
\text { Key } \\
\text { Global) }\end{array}$ & $\begin{array}{l}\text { China } \\
\text { (CST, } \\
\text { LEED) }\end{array}$ & $\begin{array}{l}\text { Japan } \\
\text { (GSTC) }\end{array}$ & $\begin{array}{l}\text { Singa- } \\
\text { pore } \\
\text { (MICE) }\end{array}$ & $\begin{array}{l}\text { ASEAN } \\
\text { country } \\
\text { (ATSP, } \\
\text { AGHS) }\end{array}$ \\
\hline Policy plan & $\bullet$ & - & - & - & - & $\bullet$ & $\bullet$ & - & - & - \\
\hline Human resource & - & - & - & - & - & - & - & - & - & - \\
\hline Green products & $\bullet$ & $\bullet$ & $\bullet$ & $\bullet$ & $\bullet$ & $\bullet$ & $\bullet$ & $\bullet$ & $\bullet$ & $\bullet$ \\
\hline $\begin{array}{l}\text { Community } \\
\text { Collaboration }\end{array}$ & $\bullet$ & $\bullet$ & $\bullet$ & $\bullet$ & $\bullet$ & $\bullet$ & $\bullet$ & $\bullet$ & $\bullet$ & $\bullet$ \\
\hline $\begin{array}{l}\text { Energy } \\
\text { Management }\end{array}$ & - & $\bullet$ & - & - & $\bullet$ & - & - & $\bullet$ & $\bullet$ & - \\
\hline $\begin{array}{l}\text { Waste } \\
\text { Management }\end{array}$ & - & - & - & - & - & - & - & - & - & - \\
\hline $\begin{array}{l}\text { Water } \\
\text { Management }\end{array}$ & - & - & - & - & - & $\bullet$ & - & - & $\bullet$ & $\bullet$ \\
\hline $\begin{array}{l}\text { Air Quality } \\
\text { Management }\end{array}$ & - & - & - & - & - & - & - & - & - & - \\
\hline $\begin{array}{l}\text { Noise } \\
\text { Management }\end{array}$ & - & - & - & - & - & - & - & $\bullet$ & - & - \\
\hline Green Growth & - & & & & & & & - & & \\
\hline Land & - & & & & & & & & & \\
\hline Marine \& Coast & - & & - & & - & & & - & - & \\
\hline $\begin{array}{l}\text { Urban } \\
\text { Environment }\end{array}$ & - & & & - & & - & & $\bullet$ & $\bullet$ & \\
\hline $\begin{array}{l}\text { Nature \& } \\
\text { Biodiversity }\end{array}$ & - & & - & - & - & - & - & - & & \\
\hline Soil Management & - & & & - & & & & - & & \\
\hline
\end{tabular}

In addition, this study found that the most significant and pertinent initiatives of SFM focus only on nine key initiatives that are most required and useful specifically for the hotel industry. The nine key initiatives identified were must are policy, human resource, green products, community collaboration, energy management, water management, waste management, air quality management and noise management (Table 3). Table 3 below shows a report on the SFM key initiatives that are most significant for the implementation in the hotel industry in Malaysia.

Based on Table 4 above, many researchers focus on managing and coordination of human resources within the organization to achieve sustainable goals. According to ASEAN (2016), the SFM scope of human resource management in the hotel industry is to deliver the training programs for the operation and managing the employee for the sustainable program to achieve the corporate's sustainability goals. As mentioned by Chan \& Hsu (2016), the hotel organization play an essential role in coordinate human resource and organize a strategic plan for gaining sustainable advantages.

On the other hand, recent evidence suggests that the hotel sector's contribution to global $\mathrm{CO} 2$ emissions is in the order of just $5 \%$ (in 2005), but might higher (from 5\% to 14\%) if measured as radiative forcing, i.e. the warming caused by $\mathrm{CO} 2$ as well as other greenhouse gases (UNEP, (2008); UNWTO, (2008)). This calculation only includes energy throughput and does not add the energy needed to construct hotels, airports, highways, and runways (UNEP, 2008). Since then, many studies identified that many hotels had enhanced and improved by participating in energy conservation initiatives as part of performance measurement while reducing the $\mathrm{CO} 2$ emission (Nielsen et al., 2016c). 
Table 4: Nine (9) SFM key initiatives for hotel industry

\begin{tabular}{|c|c|c|}
\hline SFM Initiatives & Literature & Authors \\
\hline $\begin{array}{l}\text { Policy } \\
\text { (Strategic plan) }\end{array}$ & $\begin{array}{l}\text { - Various hotel brands have made an effort to change corporate policy/cultures in strategizing } \\
\text { to be more environmentally responsible } \\
\text { - Hotels have gone ahead to adopt facilities management as one of their strategic management } \\
\text { instruments to improve the performance of their hotels }\end{array}$ & $\begin{array}{l}\text { (Junghans, 2011) } \\
\text { (Londoño et al., 2016) } \\
\text { (Nielsen et al., 2016b) }\end{array}$ \\
\hline Human resource & $\begin{array}{l}\text { - Organizations should manage their human resources correctly, specifically involving the } \\
\text { - } \quad \text { The coordination between the organizations' business strategies and strategic human } \\
\text { resources plays a vital role in gaining a sustainable advantage. } \\
\text { - The involvement of human resources such as top management support, sustainable training, } \\
\text { employee empowerment, teamwork and rewards systems is essential in the critical success } \\
\text { factor of sustainability programs of SFM initiatives. } \\
\text { - The sustainability long term success can also be affected by management practices such as } \\
\text { human resource involvement } \\
\text { The hoteliers should stimulate the sustainable commitment of the staff through the human } \\
\text { resources management by providing fair treatment and remuneration, offering promotion } \\
\text { opportunities, encouraging the atmosphere of partnership, and implementing other practices } \\
\text { improving staff wellbeing in the workplace. } \\
\text { Disseminate green practice information }\end{array}$ & $\begin{array}{l}\text { (Kutanis, et al., 2012) } \\
\text { (E. S. W. Chan \& Hsu, 2016) } \\
\text { (Fotiadis, et al., 2013) } \\
\text { (Bohdanowicz, et al., 2016) }\end{array}$ \\
\hline Green products & $\begin{array}{l}\text { - Green products advantages in functional aspects of tangible service product attribute and are } \\
\text { directly related to the reduction in environmental impact. } \\
\text { Many hotels organization have tried in modifying their existing products/services to be more } \\
\text { environmentally friendly. }\end{array}$ & $\begin{array}{l}\text { (Yi, Li, \& Jai, 2016) } \\
\text { (Londoño et al., 2016) }\end{array}$ \\
\hline $\begin{array}{l}\text { Community } \\
\text { collaboration }\end{array}$ & $\begin{array}{l}\text { - A study found that hotel guests prefer recycling bins, waste, site, and linen reuse because } \\
\text { these practices could implement through cooperation between hotels and guests. }\end{array}$ & (Yi et al., 2016) \\
\hline Energy management & 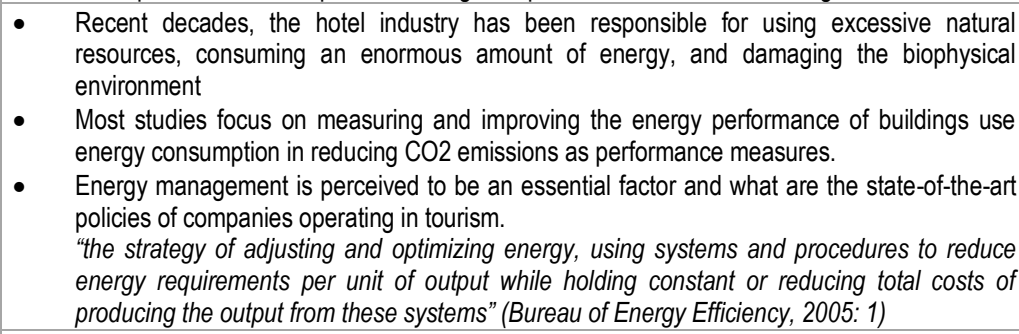 & $\begin{array}{l}\text { (Bohdanowicz et al., 2011; } \\
\text { Horng et al., 2017) } \\
\text { (Nielsen, Sarasoja, \& Galamba, } \\
\text { 2016c) } \\
\text { (Mendes \& Santos, 2014) }\end{array}$ \\
\hline Water management & $\begin{array}{l}\text { - Many pieces of evidence that hotel realize the water-saving practices are potential in reduced } \\
\text { operational cost } \\
\text { The study revealed the most popular environmentally friendly practices adopted by the facilities } \\
\text { surveyed were; use of energy-saving bulbs, reuse of towel and napkin, use of reusable items } \\
\text { such as ceramic cups and plates and training of staff on environmentally friendly practices } \\
\text { such as water conservation, energy conservation and waste management. }\end{array}$ & $\begin{array}{l}\text { (Bohdanowicz et al., 2011) } \\
\text { (Bohdanowicz, 2005) } \\
\text { (W. W. Chan, 2005) } \\
\text { (Razumova et al., 2016) } \\
\text { (Kuuder et al., 2013) } \\
\text { (Elmualim et al., 2012) }\end{array}$ \\
\hline Waste management & $\begin{array}{l}\text { - The hotel uses recyclable products, paper, glass, metal, plastic, or cardboard. Placing } \\
\text { recycling bins in each guest room is also considered a recycling practice. } \\
\text { - Production costs can be reduced in the medium and long term as they would be investing in } \\
\text { solutions that avoid/minimize waste } \\
\text { - The volume of water used in a unit will depend on the water-saving potentials, which varies } \\
\text { significantly at hotels depending on the type of facility and the occupancy rate of the hotel. } \\
\text { Besides guest rooms and other ranges include landscape irrigation, office and staff areas, food } \\
\text { service/preparation conference and banquet, special facilities, laundry and others. }\end{array}$ & $\begin{array}{l}\text { (Yi et al., 2016) } \\
\text { (Mendes \& Santos, 2014) } \\
\text { (Sadi \& Adebitan, 2014) }\end{array}$ \\
\hline $\begin{array}{l}\text { Air quality } \\
\text { management }\end{array}$ & $\begin{array}{l}\text { - Improves indoor air quality will also save energy if the Heating, Ventilating and Air Conditioning } \\
\text { Manufacturers Association (HVAC) controlled and monitored based on the usage needed }\end{array}$ & $\begin{array}{l}\text { (Järvensivu, 2014) } \\
\text { (Dixit, et al., 2016) }\end{array}$ \\
\hline Noise management & $\begin{array}{l}\text { - Improvements on the indoor acoustic environment, where noise from building equipment such } \\
\text { as fans, boilers and compressors could negatively impact the guest experience. }\end{array}$ & (Goldstein \& Primlani, 2012) \\
\hline
\end{tabular}

Moreover, the hotel's comprehensive water reduction efforts have shown considerable benefit. Many shreds of evidence have highlighted that improvements in water conservation also potential to recuperate operational cost (Bohdanowicz et al., 2011; W. W. Chan, 2005; Elmualim et al., 2009; Nielsen et al., 2016). Water conservation can be done by aerated, reduced in pressure, and recycled as a means to reduce water waste. One of the most popular ways that hotels have reduced water consumption is replacing current appliances with water-efficient ones, including laundry facilities, toilets, showers, and faucets (Bruns-smith et al., 2015). For instance, one study showed that installing low-flow showerheads and aerated faucets saved $\$ 1.50$ per room per month for one hotel, and using water-efficient toilets kept the hotel 180,000 gallons of water per year (Bruns-smith et al., 2015; Cornell University, 2017). Therefore, there are numerous efforts and effective ways for the implementation of water conservation. Hence, the nine key SFM initiatives have shown that all the evidence of several studies has conducted SFM initiatives pertaining to the sustainability provision in the hotel industry.

\subsection{Conclusion}

The primary purpose of this study is to explore the SFM key initiatives for the hotel industry. The SFM practice in chronological development across the globe attained from the meta-analysis method on the SFM trends developing. The findings of this paper identified 
a total of 15 initiatives across the world, but the hotel industry adopted only nine key initiatives of SFM. The nine key initiatives identified were must are policy, human resource, green products, community collaboration, energy management, water management, waste management, air quality management, and noise management. The implementation of SFM initiatives are essential in hotel industry to gain a successful holistic sustainable practice. SFM practice in the hotel often considers as the company's sustainability disclosures in their assessment of management quality and efficiency and reporting may provide the hotel better access to its capital. To sum up, the benefits of SFM practice go beyond relating financial and opportunity of their performance enhancement but as well improvement of the hotel brands. Hence, this research sheds light on SFM practices which later intended to develop a framework of SFM in the hotel industry.

\section{Acknowledgments}

The author would like to acknowledge the contribution from the Institute of Research Management \& Innovation (IRMI) of University Teknologi MARA (UiTM) through supporting the research-:Geran Insentif Penyeliaan (GIP): 600-IRMI 5/3GIP (016/2019).

\section{References}

Alexander, K. (2009). European Facilities Management - The Next Generation. Retrieved from www.eurofm.org

Alonso-Almeida, M. del M., Fernández Robin, C., Celemín Pedroche, M. S., \& Astorga, P. S. (2017). Revisiting green practices in the hotel industry: A comparison between mature and emerging destinations. Journal of Cleaner Production, 140, 1415-1428. https://doi.org/10.1016/j.jclepro.2016.10.010

ASEAN. (2016). ASEAN Green Hotel Standard. In Public Outreach and Civil Society Division of the ASEAN Secretariat, Jakarta. Retrieved from http://www.asean.org/wpcontent/uploads/2012/05/ASEAN-Green-Hotel-Standard.pdf

Baaki, T. K., Baharum, M. R., \& Ali, A. S. (2016). A review of sustainable facilities management knowledge and practice. MATEC Web of Conferences, 66, 1-10. https://doi.org/10.1051/matecconf/20166600075

Bohdanowicz, P. (2005). European hoteliers' environmental attitudes: Greening the business. Cornell Hotel and Restaurant Administration Quarterly, 46(2), $188-204$. https://doi.org/10.1177/0010880404273891

Bohdanowicz, P., Zientara, P., \& Novotna, E. (2011). International hotel chains and environmental protection : an analysis of Hilton's we care ! programme (Europe , 2006 - 2008). Journal of Sustainable Tourism, 19, 37-41. https://doi.org/10.1080/09669582.2010.549566

Bowen, G. A. (2009). Document analysis as a qualitative research method. Qualitative Research Journal, 9(2), 27-40. https://doi.org/10.3316/QRJ0902027 British Institute of Facilities Management (BIFM). (2018). EMBRACING WORKPLACE TO.

Brundtland International Institute for Sustainable Development. (2017). Sustainable Development | IISD. Retrieved April 19, 2017, from http://www.iisd.org/topic/sustainable-development

Bruns-smith, A., Choy, V., Chong, H., \& Verma, R. (2015). Environmental Sustainability in the Hospitality Industry : Best practices, Guest Participation, and Customer Satisfaction. Cornell Hospitality Report, Vol. 15, pp. 6-16. https://doi.org/10.1017/CBO9781107415324.004

Chan, E. S. W., \& Hsu, C. H. C. (2016). Environmental management research in hospitality. International Journal of Contemporary Hospitality Management, 28(5), 886923. https://doi.org/10.1108//JCHM-02-2015-0076

Chan, W. W. (2005). Partial analysis of the environmental costs generated by hotels in Hong Kong. International Journal of Hospitality Management, 24(4), 517-531. https://doi.org/10.1016/j.ijhm.2004.10.008

Chotipanich, S. (2006). Positioning Facility Management. Facilities, 22(13/14), 364-372. https://doi.org/10.1108/02632770410563086

Cornell University. (2017). Hotel Operations Management. Retrieved March 17, 2017, from https://www.sce.cornell.edu/sc/programs/index.php?v=172

Creswell, J. W. (2014). Research Design: Qualitative, Quantitative and Mixed Methods Approaches (Fourth). California: Sage Publications, Inc.

Dixit, M. K., Culp, C. H., Fernandez-Solis, J. L., \& Lavy, S. (2016). Reducing carbon footprint of facilities using a facility management approach. Facilities, 34(3/4), 247259. https://doi.org/10.1108/F-11-2014-0091

Durodola, O. D., Abiodun Ayedun, C., \& Omolade Adedoyin, A. (2012). Beneficial application of facilities management in hotel organizations in south-western Nigeria. Mediterranean Journal of Social Sciences, 3(1), 413-423. https://doi.org/10.5901/mjss.2012.03.01.413

Elmualim, A., Valle, R., \& Kwawu, W. (2012). Discerning policy and drivers for sustainable facilities management practice. International Journal of Sustainable Built Environment, 1(1), 16-25. https://doi.org/10.1016/j.jjsbe.2012.03.001

Elmualim, A., Valle, R., Pastou, M., \& Ludlow, G. (2009). Innovation in Sustainable Facilities Management Practice : Implementing a Sustainability Policy. Facilities Management, 176-185.

Ernst and Young. (2013). 2013 Six Growing Trends in Corporate Sustainability.

Fotiadis, A. K., Vassiliadis, C. A., \& Rekleitis, P. D. (2013). Constraints and benefits of sustainable development: A case study based on the perceptions of small-hotel entrepreneurs in Greece. Anatolia, 24(2), 144-161. https://doi.org/10.1080/13032917.2012.741049 
Göğüş, G., Karakadılar, I. S., \& Apak, S. (2013). Innovation and Sustainable Growth Measurement in Hotel Industry: A Hierarchical Decision Making Model. Procedia Social and Behavioral Sciences, 99, 752-761. https://doi.org/10.1016/j.sbspro.2013.10.547

Goldstein, K., \& Primlani, R. V. (2012). Current trends and opportunities in hotel sustainability. In HVS Sustainability Services. Retrieved from http://www.hvs.com/article/5655/current-trends-and-opportunities-in-hotel-sustainability/

Hasim, M. S., Pullen, S., \& Sivam, A. (2012). Sustainability Practices in Organizations : Comparative Analysis Between Australia and Malaysia on. (December), 4-5.

Hodges, C. P. (2014). Sustainable Facility Management - The Integration of Sustainability into a Facility Manager's Core Competencies.

Horng, J.-S., Liu, C.-H., Chou, S.-F., Tsai, C.-Y., \& Chung, Y.-C. (2017). From innovation to sustainability: Sustainability innovations of eco-friendly hotels in Taiwan. International Journal of Hospitality Management, 63, 44-52. https://doi.org/10.1016/j.jhm.2017.02.005

International Facility Management Association (IFMA). (2018). A Sustainable Framework. Retrieved October 29, 2019, from IFMA Knowledge Library website: http://community.ffma.org/knowledge_library

Iwanowski, K., \& Rushmore, C. (1994). Introducing the Eco-Friendly Hotel. Cornell Hotel and Restaurant Administration Quarterly, 35(1), 34-38. https://doi.org/10.1177/001088049403500104

Järvensivu, J. (2014). Environmental Sustainability in Hotel Facilities A Case Study: Original Sokos Hotel Villa. (May). Retrieved from https://www.theseus.fi/bitstream/handle/10024/79162/Jarvensivu_Jenny.pdf?sequence=1

Jayawardena, C. (Chandi), Pollard, A., Chort, V., Choi, C., \& Kibicho, W. (2013). Trends and sustainability in the Canadian tourism and hospitality industry. Worldwide Hospitality and Tourism Themes, 5(2), 132-150. https://doi.org/10.1108/17554211311314164

Jenkins, N. R., \& Karanikola, I. (2014). Do hotel companies communicate their environmental policies and practices more than independent hotels in Dubai, UAE? Worldwide Hospitality and Tourism Themes, 6(4), 362. https://doi.org/10.1108/WHATT-01-2014-0003

Junghans, A. (2011). State of the Art in Sustainable Facility Management. 5th Nordic Conference on Construction Economics and Organisation, 553-564.

Junghans, A., \& O.E. Olsson, N. (2014). Discussion of facilities management as an academic discipline. Facilities, 32(1/2), 67-79. https://doi.org/10.1108/F-10-20120078

Kutanis, R. O., Mesci, M., Comlekci, I., \& Sahin, O. (2012). Investigating Hotel Employee Involvement in Strategic Human Resources Management. Journal of Tourism, $7(1), 117-134$.

Kuuder, C. W., Bagson, E., Prempeh, V. M., Mumuni, A., Adongo, R., \& Amoako, E. E. (2013). Energy, Water and Waste Management in the Accommodation Sector of Tamale Metropolis, Ghana. American Journal of Tourism Mnagement, 2, 1-9. https://doi.org/10.5923/s.tourism.201304.01

Lai, J. H. K., \& Choi, E. C. K. (2015). Performance measurement for teaching hotels: A hierarchical system incorporating facilities management. Journal of Hospitality, Leisure, Sport and Tourism Education, 16, 48-58. https://doi.org/10.1016/j.jhlste.2015.02.002

Londoño, M. P. L., \& Hernandez-Maskivker, G. (2016). Green practices in hotels: the case of the GreenLeaders Program from TripAdvisor. 201(St), 1-13. https://doi.org/10.2495/ST160011

Malaysia National Ecotourism Plan (MNEP). (2016). Malaysia National Ecotourism Plan 2016-2025. Ministry of Tourism and Culture Malaysia, Vol. 39, pp. 561-563.

Melissen, F., van Ginneken, R., \& Wood, R. C. (2016). Sustainability challenges and opportunities arising from the owner-operator split in hotels. International Journal of Hospitality Management, 54, 35-42. https://doi.org/10.1016/j.j.jhm.2016.01.005

Mendes, J. P., \& Santos, S. (2014). Energy Management in Four and Five Star Hotels in Algarve (Portugal). Turizam International Scientific Journal, 18(3), 95-112. Retrieved from http://www.dgt.uns.ac.rs/turizam/arhiva/vol_1803_1.pdf

Meng, X. (2015). Facilities Management: Tracing Its Development Trajectory. Property Management, 33(3), 212-223. https://doi.org/10.1108/PM-12-2013-0059

Nazeer, F. S., Gunatilake, S., \& Ramachandra, T. (2019). Significant Sustainable Facilities Management (SFM) Practices in the Health Care (HC) Sector. IOP Conference Series: Earth and Environmental Science, 290(1). https://doi.org/10.1088/1755-1315/290/1/012055

Neuman, W. L. (2014). Social Research Methods: Qualitative and Quantitative Approaches. In Teaching Sociology (7th editio, Vol. 30). https://doi.org/10.2307/3211488

Nielsen, S. B., Sarasoja, A.-L., \& Galamba, K. R. (2016a). Sustainability in facilities management: an overview of current research. Facilities, 34(9/10), 535-563. https://doi.org/10.1108//JCHM-09-2013-0421

Nielsen, S. B., Sarasoja, A.-L., \& Galamba, K. R. (2016b). Sustainability in facilities management: an overview of current research. Emerald Insight: Facilities, 34(9/10), 535-563. https://doi.org/10.1108//JCHM-09-2013-0421

Nielsen, S. B., Sarasoja, A.-L., \& Galamba, K. R. (2016c). Sustainability in facilities management: an overview of current research. Facilities, 34(9/10). https://doi.org/10.1108/IJCHM-09-2013-0421

Penny, W. Y. K. (2007). The use of environmental management as a facilities management tool in the Macao hotel sector. Emerald Insight: Facilities, 25(7/8), $286-295$. https://doi.org/10.1108/02632770710753325

Razumova, M., Rey-Maquieira, J., \& Lozano, J. (2016). The role of water tariffs as a determinant of water saving innovations in the hotel sector. International Journal of Hospitality Management, 52, 78-86. https://doi.org/10.1016/j.jihm.2015.09.011

Sadi, I. A., \& Adebitan, E. O. (2014). Waste Water Recycling in the Hospitality Industry. Academic Journal of Interdisciplinary Studies, 3(7), 87-95. 
https://doi.org/10.5901/ajis.2014.v3n7p87

United Nation Environmental Protection (UNEP). (2017). Regional Study on Mercury: Waste Management in ASEAN region.

United Nations Environment Program (UNEP). (2008). Adaptation and Mitigation in the Tourism Sector : Frameworks, Tools and Practices. https://doi.org/978-92-807$2921-5$

United Nations World Tourism Organization (UNWTO). (2008). Climate Change and Tourism Responding to Global Challenges. In United Nations Organization World Tourism, UNWTO. https://doi.org/10.1007/978-3-7908-1718-8

UNWTO. (2018). UNWTO Tourism Highlights. International Tourism Trends 2017. https://doi.org/https://doi.org/10.18111/9789284419876

Yi, S., Li, X., \& Jai, T. C. (2016). Hotel guests ' perception of best green practices : A content analysis of online reviews. Tourism and Hospitality Research, 1-12. https://doi.org/10.1177/1467358416637251

Yusof, Z. B., \& Jamaludin, M. (2013). Green Approaches of Malaysian Green Hotels and Resorts. Procedia - Social and Behavioral Sciences, 85(0), 421-431. https://doi.org/http://dx.doi.org/10.1016/j.sbspro.2014.10.083

Zaiton, S., Herman, S., Kasimu, A. B., \& Hassan, H. (2016). Sustainable tourism practices among hotels in Malaysia: financial and non-financial benefits. Journal of Sustainability Science and Management, 11(1), 73-81. 